\title{
TURKISH REGIONAL DEVELOPMENT AGENCIES AND TOURISM SECTOR
}

\author{
Uğur Çalişskan ${ }^{1}$ \\ Süleyman Toy ${ }^{2}$
}

\begin{abstract}
Turkish planned development efforts are not new but it is achieved by following other developments introduced in especially western countries. Turkish regional development policies experienced a breakthrough after early 2000s, when the country stepped forward to accept European Union policies in which mainly the statistical units are classified (NUTS) to collect data to be used to make policies. As the result of accepting such a policy, Turkey also formed statistical units all over the country in 2002 and established regional development agencies in 26 NUTS II regions in a period beginning from 2006 to 2010 to accelerate regional development and to reduce the regional developmental differences by energizing the local potentials. Among the duties of these RDAs are the preparation of regional plans, strategies, and financial support programs and they count tourism sector as crucial for the development of their region. In the present study, the importance of tourism sector for the development of the regions where the agencies work and regional plans were prepared in coordination with all partners is evaluated. In this respect, the performance of RDAs related to implemented grant programs is examined by considering and analyzing the content of their financial supports. In conclusions, the spatial alleviation of financial support and some feedbacks for national, regional and inter-regional tourism policies are provided.
\end{abstract}

Key words: Tourism, NUTS II Regions, Regional Development Agencies, Regional Development Plans, Financial and Technical Support

\section{INTRODUCTION}

Efforts to reduce socioeconomic development gaps between regions in early 1900s in especially western countries showed themselves clearly in national and regional policies requiring differentiation from the previous understanding of central policy making and incentive supports. Such changes in socioeconomic development understanding may be accepted to be a breakthrough for also regional / local economic development, which was focused on for the first time together with institutional basis involving some organizations like Regional Development Agencies (RDAs) and planning efforts such as regional development plans and sectoral strategies. The first example of RDAs is accepted to be Tennessee Valley Authority, founded in the USA in 1933 (Filiztekin, 2008; Özmen 2008). After especially the World War II, such organizations began to be established rapidly and simultaneously all across Europe until the beginning of 2000s (Çakmak, 2006; Kayasü and Yaşar, 2006).

Turkey's planned and regional development adventure is not a new event, but followed the advancements in the West. Even though it started in the last years of Ottoman

\footnotetext{
${ }^{1}$ Assistant Professor, Faculty of Tourism, Muğla Sitkı Koçman University, Muğla, Turkey

${ }^{2}$ Associate Professor, Faculty of Architecture and Design, Atatürk University, Erzurum, Turkey
} 
Empire, accelerated in modern Republic Period and mainly central investment decisions were dominant. When it came to 1960, a new public organisation (State Planning Organisation; SPO) responsible for planning and programming the socioeconomic development of the country was established aiming partly to close development gaps between the regions mainly distributing the central incentives to whole county. Almost all National Development Plans prepared by SPO contained policies towards regional developments and proposed several sub and local policies to predetermined regions in Turkey. However, maybe due to the lack of accurate planning works and efficient financial supports, such policies were either unsuccessful or inapplicable (Kayasüand Yaşar, 2006).

Unlike Turkey's unsuccessful regional development efforts, in Europe, a series of success stories were achieved by taking the new regional actors RDAs in the centre of development both politically and financially since these public or private organizations had two main functions; planning (i.e. policy developing) and supporting the projects serving for the implementation of these policies.Despite these main roles, RDAs in Europe have various authorities, roles and responsibilities such as determining problematic points and potentials of their regions and using them for the sake of regional development, and structures depending on the conditions and characteristics of their countries and regions like a public company, private - public partnership or fully public institution. Achievements of such RDAs in the West attracted the attentions of the rest of the world, especially those of the countries in very close relationship with Europe, like Turkey, where such applications were adopted to be the best practice examples and tried to be adjusted to the country by spending special efforts to incorporate local actors for a defined aim using central authority. In spite of such developments, Turkey was interested more closely in regional development policies, plans, units and DAs in a period beginning from 1999, when the country was accepted to be a candidate member of European Union.

\section{TURKISH RDAs}

Turkey's regional policies were demanded by EU to change in convenience with the system it applied for some time in its body after the Country began pre-accession negotiations. The policies adopted by the Union involve a classification system of the regions predetermined according to their characteristics to obtain statistical data which will be used in policy making and strategy development for the mentioned regions (nomenclature of territorial units for statistics; NUTS). In addition to such a statistical unit classification the Union has established strong local actors whose main duties are directly related to local socioeconomic development. From this point of view, Turkey's regional policies were focused on these two main issues during the pre-accession period. In early 2000s, Turkey's NUTS classification system was established and the country was categorized into 3 levels (NUTS I 12 regions, NUTS II 26 Regions and NUTS III 81 existent Provinces; See Table 1). Following this new system, RDAs began 
to be founded officially by the government in 2006 in 26 NUTSII regions. Foundation of these organizations was completed in 2008 on legal base and 2010 actively.

Table 1. Turkish NUTS classification

\begin{tabular}{|c|c|c|c|c|c|}
\hline \multicolumn{2}{|l|}{ NUTS I } & \multicolumn{2}{|l|}{ NUTS II } & \multirow{2}{*}{$\begin{array}{l}\text { NUTS III } \\
\text { Province* }^{*}\end{array}$} & \multirow{2}{*}{$\begin{array}{l}\text { RDAs } \\
\text { Acronym (Tur.) }\end{array}$} \\
\hline Acronym & Region & Acronym & Sub - region & & \\
\hline TR1 & İstanbul & TR10 & İstanbul & İstanbul & İstanbul DA; IstKA \\
\hline \multirow[b]{2}{*}{ TR2 } & \multirow[b]{2}{*}{ West Marmara } & TR21 & Tekirdağ & Tekirdağ, Edirne, Kırklareli & Trakya DA;Trakya KA \\
\hline & & TR22 & Balıkesir & Balıkesir, Çanakkale & $\begin{array}{l}\text { South Marmara DA / } \\
\text { GMKA }\end{array}$ \\
\hline \multirow{3}{*}{ TR3 } & \multirow{3}{*}{ Aegean } & TR31 & İzmir & İzmir & İzmir DA; İzKA \\
\hline & & TR32 & Aydın & Denizli, Aydın, Muğla & South Aegean DA/ GEKA \\
\hline & & TR33 & Manisa & Kütahya, Afyonkarahisar, Manisa, Uşak & Zafer DA/ Zafer KA/ \\
\hline \multirow{2}{*}{ TR4 } & \multirow{2}{*}{ East Marmara } & TR41 & Bursa & Bursa, Eskişehir, Bilecik & $\begin{array}{l}\text { Bursa, Eskişehir, Bilecik } \\
\text { DA/ BEBKA }\end{array}$ \\
\hline & & TR42 & Kocaeli & Kocaeli, Bolu, Düzce, Sakarya, Yalova & $\begin{array}{l}\text { East Marmara DA/ } \\
\text { MARKA }\end{array}$ \\
\hline \multirow{2}{*}{ TR5 } & \multirow{2}{*}{ West Anatolia } & TR51 & Ankara & Ankara & Ankara DA / AnkaraKA \\
\hline & & TR52 & Konya & Konya, Karaman & Mevlana DA/ MevKA \\
\hline \multirow{3}{*}{ TR6 } & \multirow{3}{*}{ Mediterranean } & TR61 & Antalya & Isparta, Antalya, Burdur & $\begin{array}{l}\text { West Mediterranean DA/ } \\
\text { BAKKA }\end{array}$ \\
\hline & & TR62 & Adana & Adana, Mersin & Çukurova DA/ ÇKA \\
\hline & & TR63 & Hatay & Hatay, Kahramanmaraş, Osmaniye & $\begin{array}{l}\text { East Mediterranean DA/ } \\
\text { DoğAKA }\end{array}$ \\
\hline \multirow{2}{*}{ TR7 } & \multirow{2}{*}{ Middle Anatolia } & TR71 & Kırıkkale & $\begin{array}{l}\text { Nevşehir, Aksaray, Kırıkkale, Kırşehir, } \\
\text { Niğde }\end{array}$ & Ahiler DA/AhiKA \\
\hline & & TR72 & Kayseri & Kayseri, Sivas, Yozgat & Oran DA/ Oran KA \\
\hline \multirow{3}{*}{ TR8 } & \multirow{3}{*}{ West Black sea } & TR81 & Zonguldak & Zonguldak, Bartın, Karabük & $\begin{array}{l}\text { West Blacksea DA/ } \\
\text { BAKA }\end{array}$ \\
\hline & & TR82 & Kastamonu & Kastamonu, Çankırı, Sinop & $\begin{array}{l}\text { North Anatolia DA/ } \\
\text { KUZKA }\end{array}$ \\
\hline & & TR83 & Samsun & Samsun, Amasya, Çorum, Tokat & $\begin{array}{l}\text { Middle Blacksea DA/ } \\
\text { OKA }\end{array}$ \\
\hline TR9 & East Black sea & TR90 & Trabzon & $\begin{array}{l}\text { Trabzon, Artvin, Giresun, Gümüşhane, } \\
\text { Ordu, Rize }\end{array}$ & $\begin{array}{l}\text { East Blacksea DA / } \\
\text { DOKA }\end{array}$ \\
\hline \multirow{2}{*}{ TRA } & \multirow{2}{*}{ Northeast Anatolia } & TRA1 & Erzurum & Erzurum, Erzincan, Bayburt & $\begin{array}{l}\text { Northeast Anatolia DA/ } \\
\text { KUDAKA }\end{array}$ \\
\hline & & TRA2 & Ağrı & Kars, Ağrı, Ardahan, Iğdır & Serhat DA/ SERKA \\
\hline \multirow{2}{*}{ TRB } & \multirow{2}{*}{$\begin{array}{l}\text { Middle - east } \\
\text { Anatolia }\end{array}$} & TRB1 & Malatya & Malatya, Bingöl, Elazığg, Tunceli & Firat KA / FKA \\
\hline & & TRB2 & Van & Van, Hakkâri, Bitlis, Muş & East Anatolia DA/ DAKA \\
\hline \multirow{3}{*}{$\mathrm{TRC}$} & \multirow{3}{*}{ Southeast Anatolia } & TRC1 & Gaziantep & Gaziantep, Adıyaman, Kilis & Silkroad DA/ İKA \\
\hline & & TRC2 & Şanlıurfa & Şanlıurfa, Diyarbakır & $\begin{array}{l}\text { Karacadağ DA/ } \\
\text { Karacadağ KA }\end{array}$ \\
\hline & & TRC3 & Mardin & Mardin, Batman, Sirnak, Siirt & Tigris DA/ DİKA \\
\hline
\end{tabular}

* the first province in the NUTS III column is the headquarter of the agencies

Duties, responsibilities and authorities of the Turkish RDAs were outlined through the Code 5449, which summarily mentions about them like the reduction of development gaps between the regions by coordinating public, private and civil society sides, using the local potentials efficiently in convenience with the principles in national 
development plans and policies. Such outlines are also in agreement with those of other RDAs all over the world including the preparation and implementation of regional development plans in the coordination with local actors, establishment of physical, economical and administrative infrastructure to determine the local potentials, transfer of technology in the cooperation of universities, international promotion and cooperation of the regions, increasing the attractiveness of the regions for investments and their competitiveness (Özen, 2005; Berber and Çelepçi, 2005; Özer, 2007).

\section{TOURISM SECTOR AND TURKISH RDAS}

As it was aforementioned, among the main duties of Turkish RDAs are the preparation of regional development plans and sectoral strategies to determine and use local potentials for the socioeconomic development aims and provide technical and financial supports in the regions they perform activities to achieve the targets foreseen in such documents.

Tourism sector is among the sectors nearly all Turkish RDAs have been interested in since their inception. This sector is a rapidly growing sector in Turkey, which has huge potentials for the existent and newly developing tourism types. Therefore, RDAs perceived the potentials in their regions and developed some strategies in their plans to use tourism for the development of their regions. In addition, they also provided technical and financial supports to develop the sector through the hand of both public and private sectors.

In the framework mentioned above, the aim of present study is to analyze the contents of newly prepared regional development plans by Turkish RDAs together with local actors in terms of the targets and strategies for tourism sector and evaluate their supports in tourism sector.

\section{RESULTS}

After all the RDAs completed their institutionalization in 2010, they began to prepare regional development plans for 2011 - 2013 period with the participation of nearly all sides of local actors in all NUTS II regions of Turkey for the first time in Turkey's planning history. After this priceless planning experience, the RDAs prepared their second generation development plans together with local actors for their regions foreseeing 2014 - 2023 period under the coordination of Ministry of Development (former SPO). Present study is dealt with the "regional visions", "development axes", "priorities" and "measures" taking place in 26 regional development plans related to tourism sector.

Table 2 gives the ratio of the total number of strategies to those related to tourism sector in the plans. As can be seen form the table, all the plans give place to tourism sector to some extent (above 5\%). Nearly all these strategies are related to the completion of social and physical infrastructures for tourism. 
Table 2. Tourism sector in strategic decisions in the regional development plans

\begin{tabular}{|l|l|l|l|l|}
\hline & Vision & Development Axes & Priorities & Measures \\
\hline Total number & 26 & 101 & 459 & 2551 \\
\hline Related to tourism & 2 & 4 & 27 & 188 \\
\hline$\%$ & 7.7 & 4.0 & 5.9 & 7.4 \\
\hline
\end{tabular}

When spatial distribution of the strategies on tourism is taken into consideration, it can be seen that the ratio of the strategies is above $10 \%$ in the regions with high touristic potentials like East and West Mediterranean, South Aegean and Marmara as well as Silk road (Southeast Anatolia including Gaziantep) while it is close to or below 1\% in the regions with low potentials or other priory sector like industry or etc. such as Istanbul, East Marmara, Northeast Anatolia.

It was found when considered the total financial supports of RDAs to tourism sector from 2010 to 2015 in the "call for proposal" periods that generally the amount of supports excessed 100 million TL yearly (Figure 1) except for 2012. Reason for this is caused by the variability of the budget coming from central government and the RDAs' decisions for the support together with other sectors like industry, agriculture etc. It was also seen in the scope of the study that mean rate of financial support provided by RDAs to tourism sector between 2010 and 2015 ranges from 15 (by OKA) to 80 (by ÇKA) million TL.

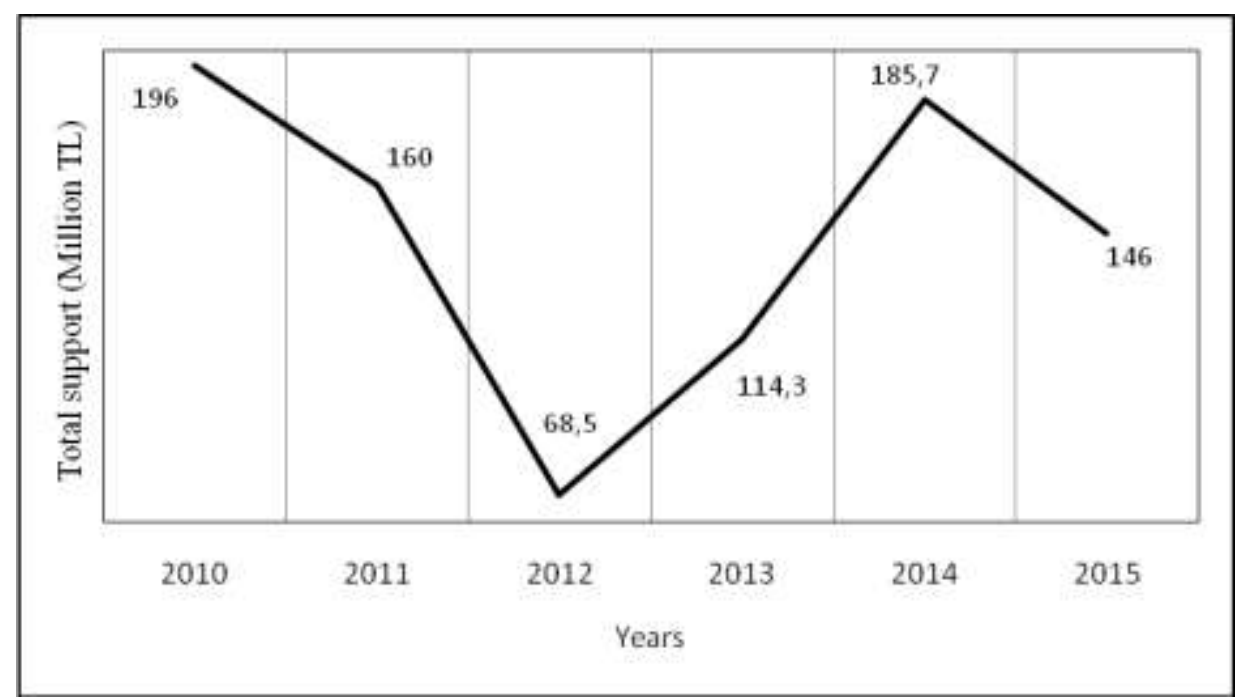

Figure 1. Amount of financial support by RDAs $(2010-2015)$

\section{CONCUSION}

Turkish RDAs are very new structures in Turkey's local economic development road story. The missions given to them are seen to be too heavy for them to lift with their present situation which goes worse and localized even though they are expected to carry and lead their regions to an upper development league. Unfortunately, they consistently 
lose power due to wrong employment and support mechanisms. Even though they started doing right things at the beginning they couldn't sustain such achievements for various reasons most important of which are administrative and political ones. Today, Turkish RDAs must be revised and their structures should be reformed even though it is a very short time since their inceptions.

Regional development plans and sectoral strategies prepared by or in coordination with local actors should be owned by other local authorities like municipalities whose budget and authorities are much more extended than the RDAs. Only in this way sectors such as tourism can be developed at local level by completing social and physical infrastructure needed. Support mechanism of RDAs in Turkey should absolutely be discussed since the amount and effectiveness of their financial supports have remained very limited and created no added value in any sectors. Instead of giving financial supports RDAs should always be consultants to prepare major projects and seek funds to implement them.

Tourism is among the vitally important sectors for Turkey since its economy is in great expectation from the sector, therefore; the sector should be developed at also regional levels by prioritizing all types of tourism in the areas with potentials. RDAs are good structures to achieve such a duty and if they work effectively on such a target Turkey's tourism may step forward and its competitiveness can increase.

\section{REFERENCES}

1. Berber M. and Çelepçi, E. (2005) Türk Bölgesel Kalkınma Politikalarında Yeni Arayışlar: Kalkınma Ajansları ve Türkiye’de Uygulanabilirliği, Doğu Karadeniz Bölgesel Kalkınma Sempozyumu, Trabzon

2. Çakmak, E.(2006), Yerel Ekonomi ve Bölgesel Kalkınma Ajansları, İmaj Yayınevi, Ankara

3. Filiztekin, A. (2008) Türkiye'de Bölgesel Farklar ve Politikalar, TÜSİAD, İstanbul

4. Kayasü S. and Yaşar, S.S. (2006) Avrupa Birliği'ne Üyelik Sürecinde Kalkınma Politikaları: Yasal ve Kurumsal Dönüşümler, Bölgesel Kalkınma ve Yönetişim Sempozyumu, Ankara

5. Özen, P. (2005), Bölge Kalkınma Ajansları, TEPAV Yayınları, İnternet Adresi: http://www.tepav.org.tr/tur/admin/dosyabul/upload/bolgeselkalkinmabilginotu.pdf, Erişim Tarihi: 07.02.2016

6. Özer, Y.E. (2007) Küresel Rekabet - Bölgesel Kalkınma Ajansları ve Türkiye, Review of Social, Economic\& Business Studies, 9/10, 389-408

7. Özmen F. (2008) AB Sürecinde Türkiye'de Bölgesel Kalkınma Ajanslarının Karşılaşabilecekleri Temel Sorun Alanları, Süleyman Demirel Üniversitesi İktisadi ve İdari Bilimler Fakültesi Dergisi 13(3), 327-340. 